\title{
IMPLEMENTASI PROBLEM BASED LEARNING (PBL) DENGAN BERMAIN PERAN (BP) TERHADAP KEMAMPUAN MEMECAHKAN MASALAH
}

\author{
Asrorul Azizi \\ asroruljilid3@gmail.com
}

\author{
Program Studi Pendidikan Ilmu Pengetahuan Alam, \\ Institut Pendidikan Nusantara Global, Indonesia, 83511
}

\begin{abstract}
Abstrak
Pembelajaran perlu memperhatikan faktor internal siswa, misalnya kemampuanmemecahkan masalah yang sangat penting artinya bagi siswa dan masa depannya. Hasil tes siswa kelas X MIA MA Darul Aminin NW Aikmual pada mata pelajaran Biologi materi pencemaran lingkungan, kemampuan memecahkan masalah tergolong rendah. Hal ini terbatas pada hasil belajar masih berorientasi pada produk, yang terbatas pada penerapan pembelajaran konsep dengan hafalan. Model pembelajaran yang digunakan dalam mengatasi masalah tersebut adalah model Problem Based Learning disertai dengan Bermain Peran (PBL BP). Penelitian ini bertujuan untuk mengetahui pengaruh dan interaksi PBL BP ditinjau dari kemampuan memecahkan masalah terhadap hasil belajar afektif, kognitif dan psikomotor. Subjek dalam penelitian ini adalah siswa kelas X MIA MA Darul Aminin NW Aikmual. Penelitian ini termasuk kedalam percobaan kuasi dengan menggunakan kelas eksperimen. Data yang diperoleh dalam penelitian ini dianalisis menggunakan uji anava. Instrumen penelitian yang digunakan lembar observasi dan tes pilihan ganda. Model PBL BP dan PBL memberikan perbedaan pengaruh terhadap hasil belajar yang baik dengan rata-rata nilai 3 aspek sebesar 86,46;. Kemampuan memecahkan masalah tinggi dan kemampuan memecahkan masalah rendah tidak memberikan hasil berarti terhadap hasil belajar dengan angka signifikansi $\leq 0,05$; 3) Interaksi model (PBL BP dan PBL) dan kemampuan memecahkan masalah meningkatkan hasil belajar dengan rata-rata ketiga aspek $0.436 \geq 0,05$.
\end{abstract}

Kata Kunci:Problem Based Learning, Bermain Peran, kemampuan memecahkan masalah.

\begin{abstract}
Learning needs to pay attention to internal factors of students, for example the ability to solve problems that are very important for students and the future. Test results for students of class X MIA MA DarulAminin NW Aikmual on Biology. Things limited to learning outcomes are still limited to products, which are limited to the application of concept learning by rote learning. The learning model used in overcoming these problems is the Problem Based Learning model won by Role Play (PBL BP). PBL BP in terms of the ability to solve problems on affective, cognitive and psychomotor learning outcomes. The subjects in this study were students of class X MIA MA DarulAminin NW Aikmual. This research was included in a quasi experiment using the experimental class. Data obtained in this study were analyzed using the Anava test. The research instrument used observation sheets and multiple choice tests. PBL BP and PBL models make a difference to good learning outcomes with an average value of 3 aspects of 86.46; The ability to solve problems and the ability to solve problems does not give results to learning outcomes with a significance value $\leq 0.05 ; 3$ ) Interaction models (PBL BP and PBL) and the ability to solve problems in improving learning outcomes with an average ability aspect of $0.436 \geq 0.05$.
\end{abstract}

Keywords: Problem Based Learning, Role Playing, problem solving skills.

\section{PENDAHULUAN}

Pada zaman globalisasi dan informasi sekarang ini, interaksi dan persaingan manusia semakin tinggi siring dengan jumlah sumber daya manusia semakin meningkat. Interaksi dan persaingan sudah melampaui batas jarak dan waktu, sehingga sumber daya manusia yang berkualitas sangat diperlukan agar mampu 
bertahan dalam persaingan. Sumber daya manusia yang unggul juga akan menunjang suatu bangsa agar mampu bersaing dan berkompetisi dengan bangsa lain. Sumber daya manusia merupakan salah satu pondasi untuk meningkatkan harkat dan martabat suatu bangsa dimata bangsa lainnya.

Pendidikan sains merupakan salah satu sektor penting dalam menghasilkan sumber daya manusia yang kompetitif dan memiliki daya saing. Biologi bagian dari sains, materinya dan konsep-konsep pembelajaran biologi banyak berhubungan dengan fenomenafenomena yang terjadi di lingkungan dan diri kita sendiri. Peraturan Menteri Pendidikan Nasional Nomor 21 Tahun 2016 tentang Standar Isi Pendidikan Dasar dan Menengah untuk muatan biologi pada SMA-MA, siswa diwajibkan memiliki kompetensi diantaranya siswa dapat menerapkan prinsip, konsep, dan hukum dalam bidang biologi. Hal tersebut mendukung terwujudnya tujuan akhir pembelajaran yang membentuk siswa yang memiliki pengetahuan dan keterampilan dalam memecahkan masalah yang dihadapi kelak di masyarakat.

Peraturan Menteri yang ada juga disesuaikan dengan perkembangan ilmu pengetahuan dan teknologi yang semakin maju saat ini, Di abad 21 ini, pendidikan menjadi semakin penting untuk menjamin peserta didik memiliki berbagai macam keterampilan. Pada abad 21, perubahan paradigma pembelajaran ke arah student-centered dan peserta didik perlu dibekali keterampilan berpikir tingkat tinggi atau Higher Order Thinking Skill (HOTS) (Sudarisman, 2015). Keterampilan tersebut salah satunya yaitu keterampilan pemecahan masalah.

Dalam proses pembelajaran saat ini, masih banyak siswa belum terbiasa berpikir kritis dalam menilai dan menanggapi persoalan. Siswa masih terbiasa meniru apa yang dicontohkan oleh guru, tanpa ada kreativitas untuk mencari alternatip jawaban lain yang lebih mudah dimengerti. Dengan kata lain kemampuan berpikir siswa hanya terbatas pada hal-hal rutin. Dalam aktivitas memecahkan masalah, diketahui bahwa siswa belum optimal dalam menyelesaikan soal pemecahan masalah (Elyani, Izzati, \& Perdana, 2019). Keterampilan memecahkan masalah bisa memberikan keterampilan lain seperti identifikasi dan kemampuan untuk mencari, memilih, mengevaluasi, mengorganisir, dan mempertimbangkan berbagai alternatif dan menafsirkan informasi atau masalah yang diberikan.

Seseorang harus mampu memberikan solusi dari beberapa sudut pandang yang berbeda-beda, terutama dalam memecahkan masalah yang kompleks. Pemecahan masalah melatih kerjasama tim, kolaborasi efektif dan kreativitas dari guru dan siswa untuk dapat menangani berbagai informasi yang sangat besar jumlahnya, dapat mendefinisikan dan memahami elemen yang terdapat pada pokok permasalahan, mengidentifikasi sumber informasi dan strategi yang diperlukan dalam mengatasi masalah. Melihat peranan dari keterampilan pemecahan masalah maka perlu adanya penerapan keterampilan pemecahan masalah dalam kegiatan pembelajaran.

Hasil analisis setelah siswa diberi tes kemampuan memecahkan masalah, hasil tes kemampuan memecahkan masalah siswa dalam memecahkan masalah masih rendah dibawah KKM dengan rata- rata yakni 60,78. Kuantitas siswa yang memperoleh nilai KKM hanya 10,34\%. Tindak lanjut dari hal ini, sebaiknya siswa sering dihadapkan pada kegiatan yang berkaitan dengan menumbuhkan memampuan memecahkan masalah.

Pembelajaran di kelas yang menjadi rutinitas dan kebiasaan dan dengan metode pembelajaran yang monoton membuat siswa kurang tertarik, sehingga pemahaman materi kurang. Pedagogi Dewey mendorong guru untuk melibatkan siswa dalam proyek berorientasi masalah dan membantu mereka menyelidiki masalah sosial dan intelektual yang penting (Arends, 2008). Kegiatan pembelajaran masih monoton dan jarang terjadi dialog, sehingga belajar dalam pemecahan masalah melalui penyelidikan maupun kegiatan lainnya masih kurang. Vigotsky yakin bahwa fungsi mental yang lebih tinggi pada umumnya muncul dalam percakapan atau kerjasama dalam 
individu, sebelum fungsi mental yang lebih tinggi terserap kedalam indivudu tersebut (Trianto, 2010).

Kemampuan memecahkan masalah oleh anak tidak dapat muncul begitu saja apabila tidak didukung dengan pembiasaan melalui pembelajaran yang aktif, berorientasi pada siswa, sehingga dibutuhkan model pembelajaran yang mendukung terbentuknya kemampuan memecahkan masalah siswa saat pelajaran. Salah satu model yang mendukung hal tersebut adalah model Problem Based Learning (PBL).

Model Problem Based Learning (PBL) merupakan salah satu model pembelajaran yang berlandaskan paradigma konstruktivistik. Teori belajar yang mendasari PBL adalah Vigotsky (scaffolding), Bruner (belajar penemuan), Ausubel (belajar bermakna), dan Piaget (perkembangan kognitif). Model pembelajaran PBL melatih dan memberikan siswa kesempatan untuk berusaha sendiri mencari pemecahan masalah serta pengetahuan yang menyertainya mampu menghasilkan pengetahuan yang benarbenar bermakna. Model PBL melibatkan kerjasama siswa secara kolaboratif pada suatu penyelidikan yang bersifat autentik untuk menyarankan kemungkinan solusi pada suatu masalah yang terjadi dikehidupan sehari-hari (Sahyar \& Yulia, 2017).

PBL memiliki ciri-ciri yaitu pembelajaran diorientasikan pada masalah, dengan sintaks yaitu: mengorientasikan siswa kepada masalah, mengorganisasi siswa untuk belajar, membimbing penyelidikan individual maupun kelompok, mengembangkan dan menyajikan hasil karya serta memamerkannya, menganalitis dan mengevaluasi proses pemecahan masalah (Nur, 2011).

Beberapa peneilitian menunjukkan keunggulan PBL dalam berbagai aspek. Hasil penelitian menunjukkan bahwa hasil keterampilan pemecahan masalah biologi pada peserta didik yang dibelajarkan menggunakan model pembelajaran berbasis masalah (PBL) lebih tinggi dibandingkan dengan peserta didik yang dibelajarkan menggunakan model pembelajaran langsung (Bahri, 2018). Perbaikan pembelajaran melalui penerapan model Problem Based Learning dalam proses pembelajaran
IPA-Biologi pada materi Ekosistem menunjukkan peningkatan antara lain menjelaskan tujuan pembelajaran dan mengarahkan siswa dalam menyajikan laporan hasil pengamatan dan motivasi belajar siswa kelas VII7 SMPN 4 Kota Bengkulu meningkat serta meningkatkan hasil belajar siswa (Dayeni, 2017).

Beberapa penelitian menunjukkan potensi PBL yaitu penerapan model PBL dapat meningkatkan kemampuan peserta didik dalam memecahkan masalah biologi (Priadi, 2012). Selain itu, terdapat hasil penelitian bahwa terdapat perbedaan kemampuan pemecahan masalah dan motivasi antara kelompok peserta didik yang belajar melalui model PBL dengan kelompok peserta didik yang belajar melalui pembelajaran langsung (Dewi, 2012).

Model PBL ini akan lebih efektif jika diterapkan dengan menggabungkan dengan metode yang mendukung siswa untuk berpikir rasional dan ilmiah, aktif dan menguasai ilustrasi ilmiah, berani dalam berpendapat, percaya diri dalam persaingan yang dinamis serta mampun menumbuhkan kedisiplinan diri. Peneliti mencoba untuk menggabungkan PBL dengan metode Bermain Peran (BP). Karena Bermain peran yaitu memainkan peranan dari peran-peran yang sudah pasti berdasarkan kejadian terdahulu, yang dimaksudkan untuk menciptakan kembali situasi sejarah masa lalu, menciptakan kemungkinan-kemungkinan masa yang akan datang, menciptakan peristiwa mutakhir yang dapat diperkaya atau mengkhayal situasi pada suatu tempat dan waktu tertentu (Dimyati \& Mudjiono, 2006). Terkait hal tersebut, simpulan dari Vigotsky yakin bahwa fungsi mental yang lebih tinggi pada umumnya muncul dalam percakapan atau kerjasama dalam individu, sebelum fungsi mental yang lebih tinggi terserap kedalam indivudu tersebut (Trianto, 2010).

Alasan lain pemilihan metode bermain peran sebagai kombinasi PBL karena melalui model pembelajaran bermain peran ini siswa diajak untuk belajar mengeksploitasi masalahmasalah hubungan antar manusia dengan cara memperagakannya, dengan bantuan kelompok sosial yang anggotanya teman-temannya sendiri 
sehingga akan sejalan dengan tujuan PBL. Pendapat lainnya mengemukakan bahwa (1) model bermain peran dibuat berdasarkan asumsi bahwa sangatlah mungkin menciptakan analogi otentik kedalam suatu situasi permasalahan kehidupan nyata (2) bermain peran dapat mendorong siswa mengekspresikan perasaannya dan bahkan melepaskan (3) proses psikilogis melibatkan sikap, nilai, dan keyakinan (belief) kita serta mengarahkan pada kesadaran melalui keterlibatan spontan yang disertai analisis (Uno, 2011).

Pemilihan materi pencemaran lingkungan merupakan salah satu materi yang membahas pada semester genap di kelas X, mengenai masalah pencemaran lingkungan, terutama terkait masalah limbah, letak geografis dan pemukiman penduduk di wilayah Praya. Melihat kondisi demikian perlu adanya penerapan materi pembelajaran yang dapat meningkatkan kemampuan pemecahan masalah siswa dalam memberikan saran untuk solusi guna menunjang hasil belajar dan menjadikan proses belajar mengajar optimal agar tujuan pembelajaran tercapai. Berdasarkan uraian di atas, perlu dilaksanakan penelitian Implementasi Problem Based Learning (PBL) dengan bermain peran (BP) terhadap kemampuan memecahkan masalah.

Adapun tujuan penelitian adalah untik mengetahui: 1) Pengaruh model PBL dengan bermain peran (PBL BP) dan PBL terhadap hasil belajar; 2) Pengaruh Kemampuan memecahkan masalah terhadap hasil belajar; 3) Interaksi model PBL dengan bermain peran (PBL BP) dan PBL dengan kemampuan memecahkan masalah terhadap hasil belajar.

\section{METODE}

Penelitian ini dilaksanakan di MA NW Aikmual Kecamatan Praya kabupaten Lombok tengah pada bulan Juli 2019 sampai September 2019. Metode yang digunakan adalah eksperimen. Kelompok eksperimen 1 diajar dengan model PBL dengan Bermain Peran (PBL BP) dan kelompok eksperimen 2 di ajar dengan model PBL. Variable bebas meliputi model model PBL BP dan model PBL, variable terikat adalah hasil belajar dan variable moderator meliputi kemampuan memecahkan masalah. Instrumen penelitian ini terdiri dari perangkat pembelajaran dan instrument pengumpulan data. Perangkat pembelajaran yang digunakan yaitu silabus, RPP, dan LKS. Pengumpulan data menggunakan tes pilihan ganda untuk mengukur hasil belajar kognitif dan kemampuan memecahkan masalah, serta lembar observasi untuk mengukur data afektif dan psikomotor siswa.

Data hasil belajar, kemampuan menyelesaikan masalah diperoleh setelah melakukan pembelajaran. Data observasi didapat pada saat melakukan pembelajaran. Data yang diperoleh selanjutnnya akan dianalisis kemudian dilanjutkan dengan uji anava. Uji statistic dilakukan pada taraf signifikansi 5\%. Sebelum dilakukan analisis statistik, dilakukan uji prasyarat yaitu uji homogenitas dan normalitas pada data.

\section{HASIL DAN PEMBAHASAN}

Data penelitian ini diperoleh melalui tes hasil belajar dan kemampuan memecahkan masalah. Sedangkan data hasil belajar aspek afektif dan psikomotor di dapat dari hasil observasi pada saat kegiatan pembelajaran berlangsung. Deskripsi data kemampuan menyelesaikan masalah disajikan pada tabel 1 .

\section{Tabel 1.}

\begin{tabular}{cccccc} 
Data & Hasil & \multicolumn{2}{c}{ Kemampuan } & \multicolumn{2}{c}{ Memecahkan } \\
Masalah Siswa & Kelas PBL & \multicolumn{2}{c}{ dan Kelas Kontrol } \\
\hline Kelas & $\begin{array}{c}\text { Jlh } \\
\text { siswa }\end{array}$ & $\begin{array}{c}\text { Nilai } \\
\text { terendah }\end{array}$ & $\begin{array}{c}\text { Nilai } \\
\text { tertinggi }\end{array}$ & $\begin{array}{c}\text { Nila } \\
\text { rata- } \\
\text { rata }\end{array}$ \\
\hline $\begin{array}{c}\text { PBL } \\
\text { BP }\end{array}$ & 30 & 70 & 90 & 86.18 \\
\hline PBL & 28 & 70 & 87 & 82,8 \\
\hline
\end{tabular}

Tabel tersebut menjelaskan bahwa model PBL BP dan PBL memiliki nilai ratarata kemampuan memecahkan masalah hampir sama, hanya terpaut 2.83 nilai saja. Hal ini dapat diartikan bahwa antara kelas yang menggunakan model PBL memiliki kemampuan rata-rata lebih rendah daripada hanya yang menggunakan PBL BP. Data rata-rata hasil belajar berdasarkan model dan kemampuan memecahkan masalah siswa disajikan pada Gambar 1. 


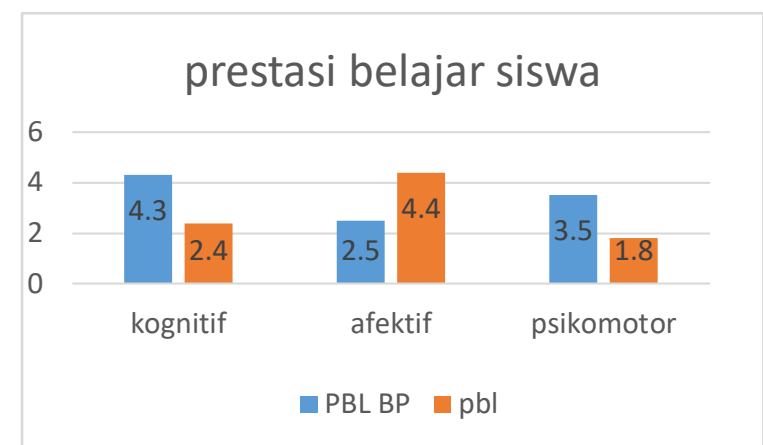

Gambar 1: Rata-rata Hasil Belajar Berdasarkan Model

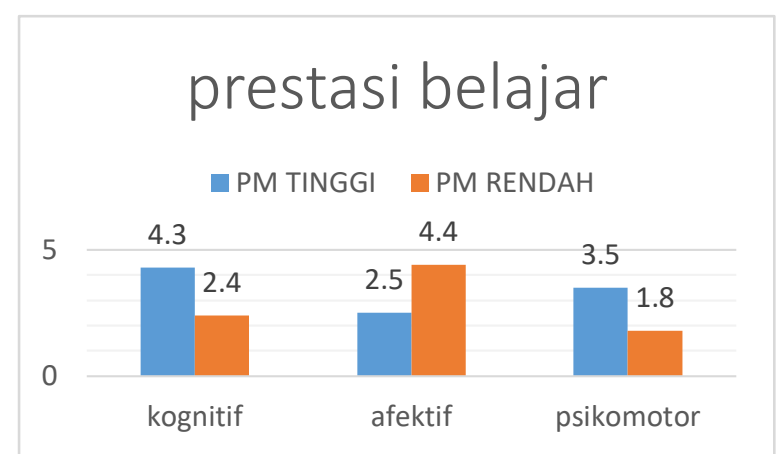

Gambar 2: Rata-rata Hasil Belajar Berdasarkam

Kemampuan Pemecahan Masalah

Gambar 1 menunjukkan bahwa skor rata-rata ketiga aspek hasil belajar siswa dengan model PBL BP lebihbaik dibandingkan dengan menggunakan model PBL. Selanjutnya skor rata-rata hasil belajar siswa berdasarkan kemampuan menyelesaikan masalah yang diajar menggunakan model PBL BP lebih baik dibandingkan dengan siswa yang diajar menggunakan model PBL (Gambar 2). Simpulan yang dapat ditarik dari Gambar 1 dan Gambar 2 bahwa, penerapan model PBL BP menunjukkan hasil yang lebihbaik. Hal ini sejalan dengan penelitian yang dilakukan bahwa penelitian menggunakan model PBL berpengaruh terhadap hasil belajar siswa yang meningkat daripada sebelumnya, hasil belajar dikatakan lebih meningkat (Redhana, 2013). Data yang diperoleh selanjutnya akan diolah menggunakan analisis statistic anava. Rangkuman hasil uji Anava disajikan pada Tabel 2.
Tabel 2.

Data Hasil hasil uji Anava

\begin{tabular}{cccccc}
\hline No & Hipotesis & \multicolumn{3}{c}{ Sig 0,05 } & \multirow{2}{*}{ keputusan } \\
\cline { 3 - 5 } & & Kognitif & Afektif & Psikomotor & \\
\hline 1 & Model & 0,026 & 0,185 & 0,049 & Diterima \\
\hline 2 & Kemampuan & 0,033 & 0,026 & 0,005 & Ditolak \\
& $\begin{array}{c}\text { Memecahkan } \\
\text { Masalah }\end{array}$ & & & & \\
\hline 3 & Model* & 0,032 & 0,571 & 0,026 & Diterima \\
& Kemampuan & & & & \\
Memecahkan & & & & \\
\hline & Masalah & & & \\
\hline
\end{tabular}

Berdasarkan tabel di atas, dapat kita lihat nilai signifikansi berdasarkan hasil analisis. Hipotesis pertama diterima yang berarti Pembelajaran dengan model PBL BP secara signifikan lebih baik dalam meningkatkan hasil belajar di banding dengan menggunakan PBL. Keunggulan PBL BP yaitu membentuk siswa yang bisa menghayati dan berani mengemukan pendapat untuk lebih memahami isi pelajaran. Sesuai dengan simpulan dari Brunner dengan siswa melakukan sendiri kegiatan pembelajaran, maka akan benar-benar menjadi pengetahuan yang bermakna (Dahar, 2006). Terkait hal tersebut, hakikat masalah dalam PBL adalah kesenjangan antara situasi nyata dengankondisi yang diharapkan (Sanjaya, 2007). Serangkaian kegiatan dalam Bermain peran membantu peserta didik mampu menemukan jawabannya, atas dasar penghayatan saat melakukan kegiatan atau mengambil peran dalam pembelajaran dan kemampuannya dalam berinteraksi.

Hipotesis kedua menunjukkan kemampuan pemecahan masalah tidak berpengaruh signifikan dalam menentukan prestasi belajar siswa dan hipotesis ketiga menunjukan adanya pengaruh yang signifikan terhadap prestasi belajar karena adanya interaksi Model dengan kemampuan memecahan masalah.

Model PBL BP yang diterapkan dalam pembelajaran dapat meningkatkan hasil belajar siswa. Kemampuan memecahkan masalah dipandang perlu dimiliki siswa, terutama siswa SMA/MA, karena kemampuan-kemampuan ini dapat membantu siswa membuat keputusan yang tepat, cermat, sistematis, logis, dan mempertimbangkan berbagai sudut pandang. Sebaliknya, kurangnya kemampuankemampuan ini mengakibatkan siswa pada 
kebiasaan melakukan berbagai kegiatan tanpa mengetahui tujuan dan alasan melakukannya.

Peneliti berkesimpulan bahwa

kemampuan memecahkan masalah sebaiknya mulai dilatih dan diberdayakan sedari saat ini sebagai latihan mempersiapkan anak didik dalam menghadapi pemecahan masalah di kehidupan nyata jika mereka nanti lulus tingkat SMA/MA.

Penggunaan model yang tepat dalam pembelajaran dapat berpengaruh terhadap pertumbuhan kemampuan yang dimiliki siswa dalam menyelesaikan masalah. Penelitianini model PBL BP memberikan hasil yang baik terhadap hasil belajar siswa. Model PBL BP dapat membantu dalam meningkatkan hasil belajar siswa salah satu kelebihan PBL BP adalah siswa memiliki kepercayaan diri untuk mengaplikasikan pengetahuan yang mereka miliki dan mengarahkan dan mengembangkan pengetahuan baru siswa dengan berfikir rasional dan ilmiah memahami masalah dalam kehidupan yang nyata.

Teori pendukung yakni Ausebel bahwa belajar ditekankan pada belajar bermakna (Dahar, 2006). Relevansi teori Ausebel dengan PBL BP dalam penelitian ini adalah pada sintak pertama dan kedua yaitu dalam hal ini untuk mengetahui kemampuan awal dan siswa memperoleh pengetahuan baru melalui percobaan dan penghayatan mengenai pencemaran lingkungan, sintak ketiga PBL dimana siswa akan dibimbing memperoleh pengetahuan baru melalui serangkain percobaan dalam hal ini disajikan dalam bentuk bermain peran berkaitan dengan pencemaran lingkungan sehingga lebih menarik, dan selanjutnya sintak ke empat PBL dimana siswa secara berkelompok akan menyajikan hasil percobaan yang diperoleh melalui bermain peran. Rangkaian belajar menjadi lebih bermakna karena informasi yang disusun sesuai struktur kognitif yang siswa miliki, harapannya ingatan siswa menjadi lebih baik dan bisa tersimpan dalam waktu yang lebih lama serta bisa diterapkan dalam kehidupan sehari-hari. Teori Ausubel juga relevan dengan PBL BP, siswa tidak hanya melakukan penyelidikan tetapi juga berusaha mengkaitkan konsep terkait pencemaran lingkungan dengan serangkaian kegiatan dialog selama proses belajar berlangsung. Penemuan konsep-konsep baru menjadi bermakna karena tidak dalam proses menghafal semata akan tetapi dengan cara mereka sendiri melakukan dan berpikir disertai beberapa scenario dalam Bermain Peran.

\section{KESIMPULAN}

Berdasarkan hasil penelitian dapat simpulkan bahwa: 1) Model (PBL BP dan PBL) memberikan pengaruh terhadap hasil belajar yang baik dengan rata-rata nilai 3 aspek sebesar 86,46 ; 2). Kemampuan memecahkan masalah tinggi dan kemampuan memecahkan masalah rendah tidak memberikan hasil berarti terhadap hasil belajar dengan angka signifikansi $\leq 0,05 ; 3$ ) Interaksi model (PBL BP dan PBL) dan kemampuan memecahkan masalah meningkatkan hasil belajar dengan rata-rata ketiga aspek $0.436 \geq 0,05$;

\section{SARAN}

Saran yang diberikan sebagai tindaklanjut penelitian ini agar dalam proses pembelajaran, guru memiliki inisiatif untuk melakukan inovasi dalam pembelajaran yang menyenangkan agar proses pembelajaran bisa berjalan dengan baik dan memberikan kesan yang mendalam bagi setiap siswa

\section{UCAPAN TERIMA KASIH}

Artikel ini merupakan publikasi hasil penelitian yang dilaksanakan di MA Darul Aminin NW Aikmual, Kecamatan Praya Kabupaten Lombok Tengah. Oleh karena itu penulis mengucapkan terimakasih kepada Kepala Madrasah dan uru Biologi atas dukungan dan kesempatannya penelitian demi kesuksesan penelitian ini.

\section{DAFTAR PUSTAKA}

Arends, R. (2008). Learning To Teach. Belajar Untuk Mengajar (7nd ed.). (Prayitno, \& Mulyani, Trans.) Yogyakarta: Pustaka Pelajar.

Bahri, A. (2018, September). Peran PBL dalam Meningkatkan Keterampilan Pemecahan Masalah. Jurnal Sainsmat, VII(2), 114124. Retrieved from http://ojs.unm.ac.id/index.php/sainsmat

Dahar, R. W. (2006). Teori-Teori Belajar dan Pembelajaran. Jakarta: Erlangga. 
Dayeni, F. (2017). Upaya Meningkatkan Motivasi dan Hasil Belajar Siswa Melalui Problem Based Learning. Diklabio: Jurnal Pendidikan dan Pembelajaran Biologi, I(1), 29-36.

Dewi, P. (2012). Pengaruh Model ProblemBased Learning Terhadap Kemampuan Pemecahan Masalah Fisika Melalui Pengendalian Bakat Numerik Peserta didik SMP. e-Journal Program Pascasarjana Universitas Pendidikan Ganesha Program Studi Pendidikan IPA, IV(1), 10-19.

Dimyati, \& Mudjiono. (2006). Belajar dan Pembelajaran. Jakarta: PT Asdi Mahasatya.

Elyani, R., Izzati, N., \& Perdana, S. A. (2019). Analisis Evektifitas Model Pembelajaran ARIAS Berbatuan LKS Dalam Meningkatkan Kemampuan Pemecahan Masalah Matematis Siswa. KIPRAH, VII(2), 49-58.

Nur, M. (2011). Model Pembelajaran Berbasis Masalah. Surabaya: UNESA Press.

Priadi, M. (2012). Pembelajaran Biologi Menggunakan Problem-Based Learning Melalui Metode Eksperimen Laboraturium dan Lapangan ditinjau dari Keberagaman Kemampuan Berpikir Analitis dan Sikap Peduli Lingkungan. Inkuiri, 217-226.

Redhana, I. W. (2013). Model Pembelajaran Berbasis Masalah untuk Meningkatkan Ketrampilan Memecahkan masalah dan Berfikir Kritis. Jurnal pendidikan dan Pengajaran, 46(1), 76-86.

Sahyar, \& Yulia, R. (2017). The Effect of Problem-Based Learning Model (PBL) and Adversity Quotient (AQ) on Problem-Solving Ability. American Journal of Educational Research, V(2), 179-183.

Sanjaya, W. (2007). Strategi Pembelajaran (Berorientasi Standar Proses Pendidikan). Jakarta: Kencana Prenada Media Group.

Sudarisman, S. (2015). Memahami Hakikat dan Karakteristik Pembelajaran Biologi dalam Upaya Menjawab Tantangan
Abad 21 serta Optimalisasi Implementasi Kurikulum 2013. Florea, II(1), 29-35.

Trianto. (2010). Model-Model Pembelajaran Inovatif Berorientasi Konstrukstivistik. Jakarta: Prestasi Pustaka.

Uno, H. B. (2011). Model Pembelajaran Menciptakan Proses Belajar Mengajar yang Kreatif dan Efektif. Jakarta: PT Bumi Aksara. 